\title{
Using the Green and Ampt infiltration equation on native and plowed rangeland soils
}

\author{
NEIL C. HUTTEN AND GERALD F. GIFFORD
}

\begin{abstract}
Soll textural relationahips were used on 3 soll series on both plowed and native rangeland to prediet Green and Ampt infiltration equation parameters. Infiltration rates predicted from the Green and Ampt soil texture relationahips were regressed against field infiltration rates. Good predictabillity was found on only 4 of 94 plots, all of which were in the agricultural area. Results indicate that current soil texture relationshipa developed for eatimatine infiltration rates may not be sufficient for use in either agricultural or rangeland semiarid environments. At this point in time, if infiltration values are important, then they should be measured (not eatimated) using appropriate methodolozies.
\end{abstract}

Key Words: Green and Ampt, infiltration, soil texture, rangeland soils

Minimal research has been directed at predicting infiltration rates on western rangelands. Several examples of a multiple regression approach to predicting infiltration are available, but the equations are site specific, vary with season and among years, and some of the independent variables may be more difficult to measure than infiltration itself (Gifford and Busby 1974, Williams et al. 1972, Gifford and Skau 1967, Meeuwig 1970, Blackburn 1975, Busby and Gifford 1981, Bedunah and Sosebee 1985).

McCuen et al. (1981) have suggested that soil texture data can be used to predict Green and Ampt infiltration equation parameters on agricultural lands. The rate form of the Green and Ampt (1911) equation is:

$$
\mathrm{f}=\mathbf{K}(\mathbf{1}+\mathrm{nS} / \mathbf{F})
$$

where $\mathrm{f}=$ infiltration rate $(\mathrm{cm} / \mathrm{hr}), \mathrm{K}=$ hydraulic conductivity in the wetted zone $(\mathrm{cm} / \mathrm{hr}), \mathrm{n}=$ available porosity $(\%), \mathrm{S}=$ suction parameter $(\mathrm{cm})$, and $F=$ cumulative infiltration $(\mathrm{cm})$. The equation assumes a homogeneous soil with uniform moisture content; a negligible depth of water ponded on the surface throughout the calculation; that each plot acts as a point; and that the entire plot is contributing when runoff begins. Devaurs and Gifford (1986) were generally unsuccessful in their attempts to use soil textural relationships to predict Green and Ampt equation parameters on 3 rangeland sites on the Reynolds Creek Experimental Watershed near Boise, Idaho. The objective of this study was to determine the applicability of using rangeland soil properties on plowed and native rangeland soils to predict parameters in the Green and Ampt infiltration equation.

\section{Methods}

\section{Study Area}

During summer of 1983, 96 rainfall simulator plots were randomly located on various soil series on both agricultural land (converted from rangeland) and native rangeland in northern Utah. There were 2 sampling periods, from 9 June to 7 July,

\footnotetext{
Authors are graduate rescarch assistant and professor and chairman, Watershed Science Unit, College of Natural Resources, Utah State University, Logan 84322. Mr. Hutten is currently with AMAX Coal Co., Gillette, Wyoming and Dr. Gifford is currently chairman, Department of Range, Wildlife and Forestry, University of Nevada, 1000 Valley Road, Reno 89512.

This project was supported through the Utah Department of Public Lands and the Utah Agricultural Experiment Station, Project 749. Technical paper 3321, Utah Agricultural Experiment Station, Logan 84322.

Manuscript accepted 14 October 1987.
}

Table 1. Distribution of rainfall simulator plots with soil series during each of two sampling periods.

\begin{tabular}{cl}
\hline \hline $\begin{array}{l}\text { No. plots per } \\
\text { sampling period }\end{array}$ & Soil series with classification \\
\hline 8 & \multicolumn{1}{c}{$\begin{array}{c}\text { Plowed Area } \\
\text { Kearl loam 4-15\% slopes } \\
\text { A coarse-loamy, mixed, frigid Calcic Haploxeroll } \\
\text { Jebo very gravelly loam 25-40\% } \\
\text { slopes }\end{array}$} \\
8 & $\begin{array}{l}\text { A loamy-skeletal, mixed, frigid Calcic Haploxeroll } \\
\text { Gobine silt loam 1-10\% slopes } \\
\text { A fine-silty, mixed, frigid Typic Calcixeroll }\end{array}$
\end{tabular}

Native Area

$\begin{array}{cl}8 & \begin{array}{l}\text { Kearl loam 4-15\% slopes } \\ \text { Jebo very gravelly loam } \\ 25-40 \% \text { slopes }\end{array} \\ 8 & \text { Gobine silt loam } 1-10 \% \text { slopes }\end{array}$

("early"), and from 23 August to 15 September ("late") (Table 1). The following measurements were taken on each plot during both sampling periods:

1) Infiltration over a 30-minute period in 2- to 5-minute increments $(\mathrm{cm} / \mathrm{hr})$

2) Soil bulk density ( 2.5 and $7.6 \mathrm{~cm}$ depths)

3) Particle size distribution (soil textural class) $(2.5$ and $7.6 \mathrm{~cm}$ depths)

4) Organic matter content ( 2.5 and $7.6 \mathrm{~cm}$ depths)

5) Antecedent soil moisture ( $7.6 \mathrm{~cm}$ depth)

The climate of the area is continental and is influenced by the local topography (Campbell and Lacey 1982). It is characterized by low humidity, generally low precipitation on the valley bottom, and wide ranges in temperature. Most of the precipitation in winter falls as snow and is associated with Pacific storm fronts that move across the northern part of Utah from the west. Summer precipitation consists mainly of infrequent but often intense convective thunderstorms. Normal annual precipitation of the study area is about $44 \mathrm{~cm}$. Temperatures range from $-17^{\circ} \mathrm{C}$ in January to $27^{\circ} \mathrm{C}$ in July. Average length of freeze-free season at the study area is about 90 days. Total pan evaporation at nearby Laketown for the months May to October is $92 \mathrm{~cm}$.

Vegetation in the native area consists of sagebrush (Artemisia spp.), rabbitbrush (Chrysothamnus spp.), mule ear (Wyethia spp.), arrowleaf balsamroot (Balsamorhiza sagittata), and associated grasses and forbs. Range condition, though not determined, would probably be classified no higher than fair. In the agricultural area, vegetation consists chiefly of winter wheat with some invading forbs.

Land use in the area consisted of cattle grazing prior to plowing (1981), and continued as grazing in the native area. A majority of the study area is included in a 2,021-hectare grazing lease administered by the Utah Division of State Lands. This lease allows for grazing up to 344 animal unit months (Richard Wilcox 1984 personal communication). Actual numbers of livestock on the area at any given time are not available, however. 


\section{Field Procedures}

Infiltration rates were determined with a modular drop-forming rainfall simulator as described by Chow and Harbough (1965) and modified by Meeuwig (1971) and by Malekuti and Gifford (1978).

Runoff plots were established by driving steel frames $(61 \times 61$ $\mathrm{cm}$ ) into the soil (about $7.6 \mathrm{~cm}$ ). The soil within the plots was prewet by applying $6.4 \mathrm{~cm}$ of water 12 to 16 hours prior to rainfall simulation and covered to prevent evaporation.

The simulator was calibrated to produce $7.6 \mathrm{~cm} /$ hour rainfall intensity throughout a 30-minute run. During the first 10 minutes of rainfall, runoff samples were taken at 2-minute intervals; thereafter, samples were taken at 5-minute intervals. Based on data from Laws (1941), the kinetic energy associated with this simulator, when run at a height of $183 \mathrm{~cm}$, is about $40 \%$ of that of natural rainfall.

Average drop size was $2.8 \mathrm{~mm}$. Water was obtained from a nearby state park and was potable. Infiltration, as defined here, is rainfall minus runoff and includes water absorbed into the soil, water intercepted by vegetation, and water held in depressions and in transit across the plot surface at the moment runoff was sampled.

Surface soil characteristics were sampled following each infiltrometer run. Two samples of surface material (core diameter, 7.6 $\mathrm{cm}$; core depth, $2.5 \mathrm{~cm}$ and $7.6 \mathrm{~cm}$ ) were taken to determine bulk density $(\mathrm{g} / \mathrm{cc})$; particle size distribution was determined by the hydrometer method (Bouyoucos 1962) and soil organic matter was determined by colorimetric analysis (Sims and Haby 1971).

Average antecedent soil moisture was measured by randomly locating an additional plot frame adjacent to the 8 runoff plots on each soil series and prewetting it in the manner described above. Two soil samples were taken from this plot during the day the rainfall simulator was operated. One sample, taken in the morning was used to determine soil moisture in those runoff plots operated in the morning. The second sample taken in the afternoon represented soil moisture in the runoff plots operated in the afternoon.

Soil pits were excavated to $61 \mathrm{~cm}$ adjacent to each set of 8 plots within each map unit in both the native and agricultural areas. Soil pedon descriptions were made at each point to determine whether the site selected was indeed within the named soil series or within an inclusion. In no case did the pedon descriptions differ appreciably from those in the soil survey report of Rich County (Campbell and Lacey 1982) for the soil series indicated in Table 1.

The Green and Ampt infiltration equation (equation \#1) was fitted to $f$ versus $1 / F$ pairs for each infiltration run by least squares regression. The fitted curve was then used to determine the time to ponding. Using the standard equation of a line $Y=m X+b$ where $m$ $=$ slope and $b=$ intercept, if $Y=f$ and $X=1 / F$, the slope is $K n S$ and the intercept is $\mathbf{K}$. Separate values for $\mathbf{n}$ and $\mathbf{S}$ cannot be obtained.

The field-obtained soil texture, bulk density (both $7.6 \mathrm{~cm}$ and 2.5 cm depths), antecedent moisture data and organic matter content (7.6 cm depth) were used to predict Green and Ampt equation parameters using procedures outlined in Brakensiek et al. (1982), and modified by Brakensiek and Rawls (1984). Exponential equations which describe the texture triangles were used to obtain the Green and Ampt suction parameters, $S$, and the saturated hydraulic conductivity, Ks (Brakensiek, personal communication). The available porosity, $\mathrm{n}$, was calculated as the effective porosity, $\phi_{e}$, (from exponential formulas), minus the antecedent soil moisture. The antecedent soil moisture was obtained from field data as described above. The total porosity, $\phi$, was determined from fieldobtained bulk density data, assuming a soil particle density of 2.65 $\mathrm{g} / \mathrm{cc}$. The effective porosity, $\phi_{\mathrm{e}}$, was calculated as total porosity, $\phi$, minus residual soil water, $\phi_{\mathbf{r}}$ (from exponential formulas). The $K$ used by Brakensiek in the Green-Ampt equation is equal to onehalf the saturated hydraulic conductivity $(K=K s / 2)$ as found by Bouwer, in Brooks and Corey (1964). Using the $K$ and $n$ S thus obtained, the integrated form of the Green and Ampt infiltration equation is

$$
\mathrm{F}-\mathrm{nS}(\ln (1+\mathrm{F} / \mathrm{nS}))=\mathrm{Kt}
$$

where $t=$ time (hrs), was solved for $F$ (using Newton's method) at the time intervals used in the field.

Infiltration rates predicted from the Green and Ampt soil texture relationships were regressed against infiltration rates determined in the field. A 1:1 correspondence of texture predicted rates with field-observed rates and a zero $y$ intercept would indicate perfect predictability. T-tests were used to test whether y intercepts were equal to zero, and slopes were equal to 1 .

In determining infiltration rates by the soil texture predictors, the time scale was adjusted so preponding was initialized at the start of the rainfall. Delta $T(\Delta T)$, the time correction, is equal to TP, the time to ponding, minus TA, the equivalent time for the preponding infiltration if it had occurred with ponding conditions. The term TA was determined as follows (Hawkins, personal communication):

$$
\mathrm{TA}=((1 / \mathrm{K} *(\mathrm{FP}-\mathrm{nS} *(\ln (1+\mathrm{FP} / \mathrm{nS}))))
$$

where: $F P=$ infiltrated volume at time of ponding

$$
\begin{aligned}
& =\frac{\mathrm{nSK}}{\mathrm{i}-\mathrm{K}} \\
& \mathrm{i}=\text { rainfall application rate }(\mathrm{cm} / \mathrm{hr}) \\
& \text { other terms are defined previously. }
\end{aligned}
$$

\section{Results and Discussion}

Of 94 plots tested in early and late 1983 (data from 2 plots were unsatisfactory), only 4 plots (4\%) had intercepts equal to zero ( $\alpha=$ $0.05)$ and slopes equal to $1(\alpha=0.05)$. Of the remaining 90 plots, some had slopes equal to 1 but intercepts did not equal to zero. Others had slopes not equal to 1 but had intercepts equal to zero. Still other plots had both slopes significantly different from 1 and $y$ intercepts significantly different from zero (Table 2).

The results from 2 representative plots are shown in Figures 1 and 2 . In all cases, texture-predicted 30-minute infiltration rates were less than 30-minute rates observed in the field. Generally, the Green and Ampt texture-predicted parameters best fit the data

Table 2. Results of comparisons of texture predicted infiltration rates with ficld observed rates.

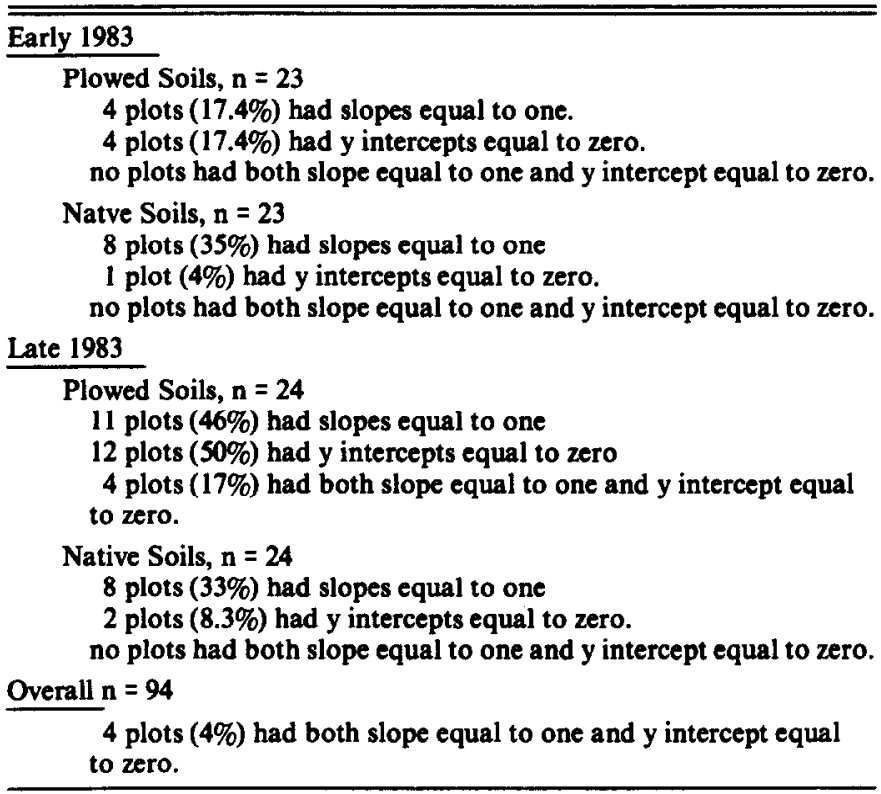



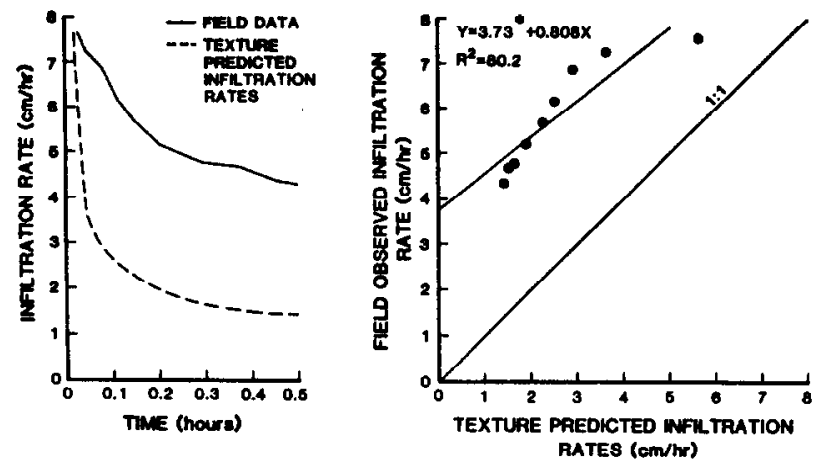

Fig. 1. Comparisons of field measured infiltration rates and texture predicted rates of 1 field plot of Kearl loam, agricultural area, early 1983. A) Field observed and texture predicted rates versus time. B) Field observed rates versus texture predicted rates. $A$ star $(*)$ indicates the intercept is significantly different from zero $(=0.05)$. Slope equals 1 . Each point represents a specific time interval.
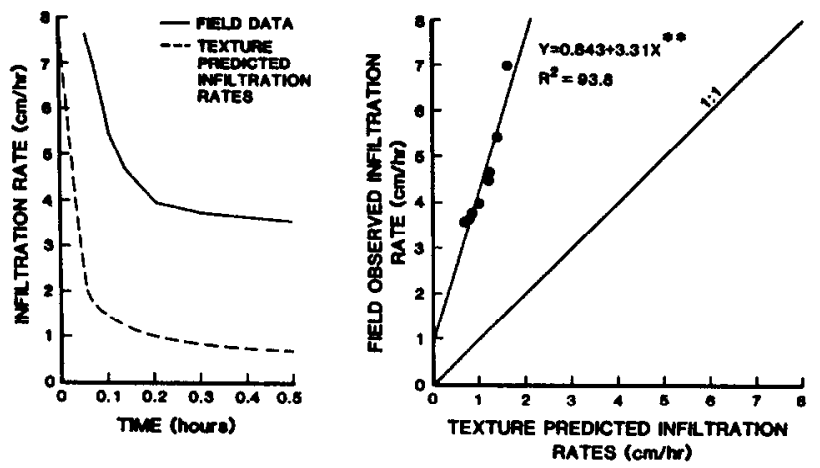

Fig. 2. Comparisons of fleld measured infiltration rates and texture predicted rates of 1 field plot of Kearl loam, native area, early 1983. A) Field observed and texture predicted rates versus time. B) Field observed rates versus texture predicted rates. Two stars $(*)$ indicates the slope different from $1(=0.05)$. Intercept equals zero. Each point represents a specific time interval.

when the infiltration rate on a given plot was low and exhibited rapid drawdown. There was usually a 1 to $4 \mathrm{~cm} /$ hour discrepancy between the field rates and the soil-texture predicted rates during the 12 to 30 -minute time interval $(0.2-0.5 \mathrm{hr})$.

The soil-texture prediction method developed for agricultural soils needs to be revised before it is suitable for use on agricultural and rangeland settings in semiarid environments. First, surface roughness and recency of plowing (or other treatment) may have a significant impact on infiltration rates (something which currently is not being considered). Second, soil porosities in this study area (and possibly others) may be higher than on sites from where the soil texture relationships were developed. Third, the role of vegetal cover and slope is not considered.

Hutten and Gifford (1988) utilized multiple regression analyses to determine important rangeland plot characteristics that affect infiltration rates on this site. Simple linear regressions on a single soil series frequently resulted in high $R^{2}$ values for a single predictor variable. However, no single plot characteristic correlated consistently with infiltration rates or erosion for all soil series. Indeed, set of predictors with the best fit often changed from the 10- to the 20 - and from the 20 - to the 30-minute infiltration rates. Furthermore, relationships between rangeland soil properties, vegetal cover, and hydrologic response change with soil series as well as season. Previous studies (Blackburn 1975, Devaurs and Gifford 1984, Gifford and Busby 1974, and Williams et al. 1972) have found similar results.

Brakensiek et al. (1982) have attempted to predict infiltration rates using bulk density, soil texture, and organic matter as the sole predictors. It is not surprising that this methodology was not successful in the present study. There are complex interrelationships between the above variables and other rangeland variables such as percent vegetal or litter cover, rooting habits, surface roughness, etc. In the long run it may be easier and more accurate to measure infiltration rates in rangeland environments than to estimate them.

\section{Summary}

Field conditions differ from the assumptions used in deriving the Green and Ampt infiltration equation. These underlying assumptions include a homogeneous soil with uniform moisture content, a negligible depth of water ponded on the surface throughout the calculation, that each plot acts as a point, and that when runoff begins the entire plot is contributing. The Green and Ampt infiltration equation also does not explicitly consider vegetation, land condition, or spatial variability. Under the field conditions in this study, all of these assumptions were not met. However, the study reported here was prompted by the current interest in the application of the Green and Ampt equation to rangeland infiltration rates.

Results indicate that Green and Ampt parameters predicted from soil texture data do not adequately reflect rangeland infiltration rates. Ninety-four plots, evenly divided between native and agricultural sites and between early and late 1983 sampling periods, were used in an attempt to validate the soil-texture predictive method for Green-Ampt parameters. Good predictability was found on only 4 plots (all in the agricultural area, late season). Predicted 30-minute infiltration rates based on soil texture were all lower than 30-minute rates observed in the field. There are limitations when soil texture predictive methods developed for agricultural lands are used to describe infiltration patterns on both native and converted rangelands. Given the current state-of-the-art, if infiltration rates are important, they should be measured in the field using appropriate methodologies.

\section{Literature Cited}

Bedunah, D.J., and R.E. Sosebee. 1985. Influence of site manipulation on infiltration rates of a depleted west Texas range site. J. Range Manage. 38:200-205.

Blackburn, W.H. 1975. Factors influencing infiltration and sediment production of semiarid rangelands in Nevada. Water Resour. Res. 11:929-937.

Busby, F.E, and G.F. Gifford. 1981. Effects of livestock grazing on infiltration and erosion rates measured on chained and unchained pinyonjuniper sites in southeastern Utah. J. Range Manage. 34:400-405.

Bouyoucos, G.J. 1962. Hydrometer method improved for making particle size analysis of soils. Agron. J. 54:464-465.

Brakenalek, D.L., W.J. Rawls, and B. Sonl. 1982. Infiltration parameter values for transient soil conditions. Winter meeting ASAE. Paper no. 82-2589.

Brakendek, D.L., and W.J. Rawls. 1984. Infiltration procedure for runoff estimation. pp A40-A50 In: Reynolds Creek Technology Transfer Symposium. 30 April-2 May 1984. Cooperative Watershed Study. Agr. Res. Serv., Boise, Ida.

Brooks, R.H., and A.T. Corey. 1964. Hydraulic properties of porous media. Hydrology Pap. 3. Colorado State Univ., Fort Collins.

Campbell, L.B., and C.A. Lacey. 1982 . Soil survey of Rich County, Utah. Soil Conserv. Serv., Washington, D.C. In cooperation with the Utah Agr. Exp. Sta., Logan.

Chow, V.T., and T.E. Harbough. 1965. Raindrop production for laboratory watershed experimentation. J. Geophys. Res. 70:6111-6120.

Devaurs, M., and G.F. Gifford. 1984. Variability of infiltration within large runoff plots on rangelands. J. Range Manage. 37:523-528.

Devaurs, M., and G.F. Gifford. 1986. Applicability of the Green and Ampt infiltration equation to rangelands. Water Resour. Bull. 22:19-27.

Gifford, G.F., and F.E. Busby. 1974. Intensive infiltrometer studies on a plowed big sagebrush site. J. Hydrol. 21:81-90. 
Gifford, G.F., and C.M. Skau. 1967. Influence of various rangeland cultural treatments on runoff and sediment production from the big sage type, Eastgate Basin, Nevada. p. 137-148, In: Proc. Third American Water Resour. Conf., San Francisco, Nov, 8-10.

Green, W.H., G. Ampt. 1911. Studies of soil physics, Part I.-the flow of air and water through soils. J. Agr. Sci. 4:1-24.

Hutten, N.C., and G.F. Gifford. 1988. Some hydrologic impacts of plowing rangeland soils. Water Resour. Bull. (in print).

Laws, J.O. 1941. Measurements of the fall-velocity of water-drops and raindrops. Trans. Amer. Geophys. Union. 22:709-721.

Malekuti, A., and G.F. Gifford. 1978. Natural vegetation as a source of diffuse salt within the Colorado River Basin. Water Resour. Bull. 14:195-205.
McCuen, R.H., W.J. Rawls, and D.L. Brakenaiek. 1981. Statistical analysis of the Brooks-Corey and Green-Ampt parameters across soil textures. Water Resour. Res. 17:1005-1013.

Meeuwis, R.O. 1970. Sheet erosion on intermountain summer ranges. U.S. Forest Serv. Res. Pap.INT-85.

Meeuwig, R.0. 1971. Infiltration and water repellancy in granitic soils. U.S. Forest Serv. Res. Pap.INT-111.

Sims, J.R., and V.A. Haby. 1971. Simplified colorimetric determination of soil organic matter. Soil Sci. 112:137-141.

Williams, G., G.F. Gifford, and G.B. Coltharp. 1972. Factors influencing infiltration and erosion on chained pinyon-juniper sites in Utah. J. Range Manage. 25:201-205. 